\title{
FACTORS AFFECTING USER BEHAVIOR OF TECHNOLOGY APPLICATION OF MANAGEMENT INFORMATION SYSTEM
}

\author{
Lisa Rosiana*), Musa Hubeis*), and Eko Ruddy Cahyadi*) \\ *) Department of Management, Faculty of Economics and Management, IPB University \\ Jl. Agatis, Kampus IPB Darmaga, Bogor 16680, Indonesia
}

\begin{abstract}
This research aimed to determine the factors influencing the behavior of management information system users at the National Accreditation Committee. The theory used was based on the Technology Acceptance Model (TAM) theory extension, and the analytical method used was the Structural Equation Model (SEM). The factors were according to Davis's modified theory, where external factors were the quality of internet connection and leadership support. Internal factors included perceived ease of use and perceived usefulness, attitudes toward using, behavioral intention to use, and actual system use. This research was conducted on 128 respondents representing the Conformity Assessment Bodies (CABs). This research showed that leadership support had a significant effect on perceived ease of use and perceived usefulness. Meanwhile, the quality of the internet connection only affected the perceived usefulness. Leadership support, quality of internet connection, perceived ease of use, perceived usefulness, and attitudes toward using were factors that affected user behavior intention to use. This research's managerial implication is to strengthen the server and increase the leadership's motivation towards the $\mathrm{CAB}$ employees by socializing accreditation applications.
\end{abstract}

Keywords: behavioral intention to use, information system, leadership support, quality of internet connection, TAM

\begin{abstract}
Abstrak: Penelitian ini bertujuan mengetahui faktor-faktor yang memengaruhi perilaku pengguna sistem informasi manajemen pada Komite Akreditasi Nasional (institusi pemerintah). Teori yang digunakan dalam penelitian ini berdasarkan pengembangan teori Technology Acceptance Model (TAM) dan metode analisis yang digunakan dalam penelitian ini adalah Structural Equation Model (SEM). Faktorfaktor dalam penelitian ini sesuai dengan teori Davis yang dimodifikasi dimana faktor dari luar berupa mutu jaringan internet dan dukungan kepemimpinan. Faktor dari dalam berupa persepsi kemudahan dan persepsi manfaat terhadap sistem, sikap untuk menggunakan sistem, kecenderungan perilaku dan penggunaan nyata. Penelitian ini dilakukan kepada 128 responden perwakilan dari Lembaga Penilaian Kesesuaian (LPK). Hasil dari penelitian ini diperoleh dukungan kepemimpinan berpengaruh signifikan terhadap persepsi kemudahan dan persepsi kemanfaatan. Sedangkan mutu jaringan internet hanya berpengaruh pada persepsi kemudahan. Faktor dukungan kepemimpinan, mutu jaringan internet, persepsi kemudahan dan persepsi kemanfaatan dan sikap dalam penggunaan berpengaruh pada kecenderungan perilaku pengguna. Implikasi manajerial dari penelitian ini adalah memperkuat server, meningkatkan motivasi pimpinan terhadap karyawan Lembaga Penilaian Kesesuaian dengan sosialisasi tentang penggunaan aplikasi akreditasi.
\end{abstract}

Kata kunci: dukungan kepemimpinan, kecenderungan perilaku pengguna, mutu jaringan internet, sistem informasi, TAM

\footnotetext{
${ }^{1}$ Corresponding author:

Email: lisarosianaprabowo@gmail.com
} 


\section{INTRODUCTION}

Currently, the development of technology and industry proliferates. In terms of service to consumers, companies and governments continue to innovate to provide the best service for technology-based service users. The National Accreditation Committee (KAN) is a government institution responsible for providing accreditation services for Conformity Assessment Bodies (CABs). KAN always tries to improve services from year to year. This is shown by the number of CABs accredited in 2018, reaching 2019 CABs. Meanwhile, the number of KAN secretariat personnel was only 100 people. The limited number of human resources causes users in CABs to complain about accreditation services, such as the delay in the KAN secretariat response. Therefore, since 2015, KAN has made the KAN Management Information System application technology called KAN MIS to provide accreditation services for CABs. However, the use of this application has found difficulty. Until 2019, there were still $5 \%$ of CABs in inspection bodies and certification bodies that have not used the KAN MIS application technology. There were also complaints regarding the internet connection quality, hard-to-understand use of the application (perhaps due to being absent in the socialization), the lack of leadership support to try new technologies, and some not functioning features such as limited download capacity.

The issue of internet connection quality was considered to influence the perception of the ease and the perceived usefulness of the KAN MIS application because the CABs located all over Indonesia had a problem with internet network when uploading the accreditation documents. This problem can be seen from the $\mathrm{CAB}$ complaints submitted in the KAN service satisfaction survey. In addition, the CAB leadership support was also an issue that affects the perceived ease of use and perceived usefulness as technology will be successfully implemented if the leader provides support for the application of new technology.

Venkatesh et al. (2003) studied the unified theory of acceptance and use of technology (UTAUT) formulated with four core determinants of behavioral intention and usage, namely performance expectancy, effort expectancy, social influence, and facilitating conditions. Neufeld and Dong (2007) studied the impacts of charismatic leadership on the four UTAUT beliefs that, in turn, influenced behavioral intention and use.
Dumpit and Fernandez (2017) studied the Technology Acceptance Model (TAM) about the impact of the quality of internet connection on perceived usefulness and perceived usefulness, and perceived ease of use; the impact of subjective norm on behavioral intention to use and actual system use. Al-Somali et al. (2009), which studied the constructs developed based on TAM, suggested that the internet connection quality had a direct relationship with perceived ease of use. Schepers et al. (2005), which also studied the constructs extended based on TAM, suggested that leadership style affected the perceived ease and perceived usefulness, especially in charismatic/transformational leadership, about how leaders inspire and motivate. Venkatesh et al. (2012) added the impacts of hedonic motivation, price value, and habit on behavioral intention and technology use as moderated by age, gender, and experience.

The application of new technology was not easy, according to the Technology Acceptance Model (TAM) developed by Davis in 1989, due to the external factors/variables, perceived usefulness (PU), perceived ease of use (PEOU), attitude toward using (ATU), behavioral intention to use (BI), and actual system use (AU). The external variable includes all variables not included in the system model (Davis 1985). There were several external variables in the researches of the TAM extension. For example, age, level of education, organizational employment category (Hubona and Kennick 1996), charismatic leadership (Schepers et al. 2005; Neufeld and Dong, 2007), quality of internet connection (Al-Somali et al. 2009; Fonchamnyo, 2013; Dumpit and Fernandez, 2017).

This research employed two external variables, namely the quality of internet connection (QIC) and leadership support (LS). QIC is an important component of internetbased applications (Fonchamnyo 2013). LS refers to a transformational leadership style with charismatic characteristics, which has individual consideration, encourages intellectual, inspires, and motivates (Schepers et al. 2005). The internal variables in this research consisted of PEOU, PU, and ATU. PEOU is a person's level of confidence that using a certain technology/system will make the business easier (Saade and Bahli, 2005). PU is the degree to which someone believes the system will contribute to achieving certain goals (Lu et al. 2003). ATU is an attitude towards the use of a system in the form of acceptance or rejection as a result when someone uses a technology/system in their work (Fishbein and Ajzen, 1975). This research 
focused on the factors influencing the KAN MIS' users' behavior, namely the CABs, inspection bodies, and certification bodies.

\section{METHODS}

This research was conducted at KAN, located at Menara Thamrin, 11th floor, J1. M. H. Thamrin Kav. 3 Kebun Sirih, Central Jakarta 10340. This research was conducted for three months, from March 2020 to May 2020 .

The data used in this study were primary and secondary data. Primary data were obtained from questionnaires given to CABs, inspection bodies, and certification bodies as accreditation services users. Secondary data were obtained by taking data published by KAN and BSN and conducting literature studies on theses, international and national scientific journals, and the internet. This research utilized online questionnaires because the CABs officer locations in this study were all over Indonesia. The answers to questionnaire questions were in the form of assessments from respondents measured using a Likert scale of 1 to 5 . The assessment started from strongly-disagree with the lowest weight to strongly-agree with the highest weight. This research was a quantitative research with variables referring to the TAM external variables in the form of quality of internet connection (QIC) and leadership support (LS), perceived usefulness (PU), perceived ease of use (PEOU), attitude toward using (ATU), the tendency of user behavior to continue to use technology or behavioral intention to use (BI), and actual system use (AU). This study's sample was determined using purposive sampling with the following criteria: having $\mathrm{CABs}$ certification body scheme and the CABs inspection body scheme registered in the KAN directory; owning active numbers enabled to access the questionnaire through Google Form; having experience in using the KAN MIS application. The number of respondents in this study was calculated using the Slovin formula, with the total number of population members as many as $188 \mathrm{CABs}$, inspection bodies, and certification bodies. It resulted in 128 respondents representing CABs nation-wide office locations. The questions sent to the respondents had previously been tested for validity with product-moment correlation and reliability by comparing the Cronbach's alpha value using IBM SPSS Statistics 21 software.
Structural Equation Modeling (SEM) was applied in this research due to its higher flexibility for social science researchers to connect theory and data (Ghozali, 2014). This study used the Partial Least Square (PLS) approach as it is not based on many assumptions, and the number of samples does not have to be large (around 100). Statistical calculations were assisted by SmartPLS version 2 software. The analysis stages using the PLS approach started from the measurement model (outer model), which specified the relationship between the latent variables and the manifest variables/ indicators, to the structural model (inner model), which specified the relationship between latent variables based on substantive theory and hypothesis testing.

The outer model assessment was conducted by determining the convergent validity of each construct. Convergent validity is used to measure the validity of each indicator by looking at the loading factor value. A value of outer loading or loading factor is said to be valid if it correlates more than 0.5 on the measured variable. The next discriminant validity assessment was the degree of conformity between variables or attributes measured by measuring instruments and theoretical concepts. Reflective discriminant validity can be used in several measures, such as cross-loading and comparing the square root of average variance extracted (AVE) value of each construct with the correlation between constructs and other constructs in the model. If the AVE square root value of each construct is higher than the correlation value between the construct and other constructs in the model, it is said to have good discriminant validity. Discriminant validity is assessed based on the cross-loading measurement with the construct. Cross-loading is used to determine the relationship between variables and indicators.

Composite reliability measures internal consistency. Its coefficient uses confirmatory factor analysis in the structural equation modeling approach. The use of composite reliability is approved to have a better advantage than usual reliability. The accepted limit value of composite reliability is 0.7 .

Inner model evaluation describes the relationship between latent variables. It aims to see the relationship between constructs and the significance value and R-square (R2) value. The relationship between constructs can be seen from the path coefficient estimation, which is the estimated value for the structural model's path relationship. The significance value can 
be obtained by comparing the $t$ statistical value with the $t$ table. In the inner model, an evaluation stage is carried out on the percentage of variance through the $\mathrm{R} 2$ value. It describes the extent to which the model can be described through each variable used. The PLS model is assessed first by looking at the R-square value to determine the effect value of certain independent latent variables on dependent latent variables. The coefficient of determination $\mathrm{R} 2$ is used to determine the extent to which the exogenous variable is able to explain the diversity of the dependent variable. The significance level reflects the strength or weakness of the relationship of each variable. The hypothesis testing stage (resampling bootstrapping) was conducted by looking at the value of the t-statistic, and the goodness of fit of this research model was calculated using the formula used by Hanseler and Sarstedt (2013) and Sholiha and Salamah (2015).

This research referred to the TAM theory presented by Davis in 1989 (Figure 1). The use of TAM, apart from explaining a system, can be accepted or rejected. This model provides input to improve the technology system to make it more acceptable to its users. TAM is the best approach to explain and predict the acceptance of information system users (Wang et al. 2005).

This study used the TAM model flow, as shown in Figure 2. This research is a TAM theory extension with external variables consisting of quality of internet connection and leadership support. Combining these two external variables has never been done in previous research and was considered appropriate to be applied to the problems in this study. In this study, there were seven studied variables: quality of internet connection, leadership support, perceived ease of use, perceived usefulness, attitude toward using, behavioral intention to use, and actual system use. The significance level used in this study was 5\%. The hypothesis was accepted if the $\mathrm{t}$-value was more than 1.96 and rejected if the $\mathrm{t}$-value was lower than 1.96. Figure 2 shows the seven studied variables: (1) quality of internet connection (QIC) consisting of 4 indicators: ease of internet access (QIC 1), the ability of the internet network to handle the online accreditation process accurately (QIC 2), internet network capability that supports 24 hours (QIC 3), and internet network capability guarantees all processes are complete (QIC 4), according to Al-Somali et al. (2009) andDumpitandFernandez(2017); (2) leadershipsupport (LS) consisting of 4 indicators: leadership instructions to use the system (LS 1), the leader thinks the system will save costs (LS 2), motivation from the leader (LS 3 ), and the leader provides the opportunity to training (LS 4), according to Schepers et al. (2005), Neufeld and Dong (2007), Venkatesh et al. (2016); (3) perceived ease of use (PEOU), consisting of 6 indicators: easy to use (PEOU 1), easy to learn (PEOU 2), interaction with the system is clear and understandable (PEOU 3), easy to control (PEOU 4), easy to understand (PEOU 5), and requires skills (PEOU 6), according to Davis et al. (1989), Wang et al. (2005), and Nasri and Charfeddine (2012); (4) Perceived usefulness (PU) or perceived usefulness consisting of 8 indicators: accelerating work (PU 1), providing digital document notifications (PU 2), increasing productivity (PU 3), increasing effectiveness (PU 4), accurate and reliable information. reliable (PU 5), safe information and data (PU 6), wellorganized information and data (PU 7), and monitoring progress (PU 8), according to Pradana and Wijaksana (2005) and Chin et al. (2004); (5) attitude toward using (ATU) consisting of 3 indicators: happy to use (ATU 1), comfortable using (ATU 2), and wise in use (ATU 3), according to Dwivedi et al. (2017); (6) behavioral intention to use (BI) consists of 3 indicators: intend to use (BI 1), choose to use (BI 2), and commitment to using (BI 3), according to Shyu and Huang (2011); (7) actual system use (AU) or actual use consists of 5 indicators: satisfaction in use (AU 1), increasing intensity of use (AU 2), each month using (AU 3), frequently using (AU 4), continues to use (AU 5), according to Wang and Shih (2009)

\section{Research Hypothesis}

Based on the application of TAM development in research related to the behavior of KAN MIS users, the proposed research hypotheses were as follows:

1. H1: Quality of internet connection (QIC) affects perceived ease of use (PEOU) in using the KAN MIS application. This hypothesis is supported by Dumpit and Fernandez (2017), Al-Somali et al. (2009), and Pikkarainen et al. (2004).

2. H2: Leadership support (LS) affects perceived ease of use (PEOU) in using the KAN MIS application. This hypothesis is supported by Schepers et al. (2005).

3. H3: Quality of internet connection (QIC) affects perceived usefulness (PU) in using the KAN MIS application. This hypothesis is supported by Dumpit and Fernandez (2017).

4. H4: Leadership support (LS) affects perceived usefulness (PU) in using the KAN MIS application. 
This hypothesis is supported by Schepers et al. (2005).

5. H5: Perceived ease of use (PEOU) affects perceived usefulness (PU) in using the KAN MIS application. This hypothesis is supported by Davis et al. (1989), Wang et al. (2005), Shyu and Huang (2011), and Manalu et al. (2020).

6. H6: Perceived ease of use (PEOU) affects attitude toward using (ATU) in using the KAN MIS application. This hypothesis is supported by Davis et al. (1989), Shyu and Huang (2011), and Nasri and Charfeddine (2012).

7. H7: Perceived usefulness (PU) affects behavioral intention to use (BI) in using the KAN MIS application. This hypothesis is supported by Davis et al. (1989), Wang et al. (2005), and Shyu and Huang (2011)

8. H8: Perceived usefulness (PU) affects attitude toward using (ATU) in using the KAN MIS application. This hypothesis is supported by Davis et al. (1989) and Nasri and Charfeddine (2012).

9. H9: Attitude toward using (ATU) affects behavioral intention to use (BI) in using the KAN MIS application. This hypothesis is supported by Davis et al. (1989), Shyu and Huang (2011), Nasri and Charfeddine (2012), and Dwivedi et al. (2017).

10. H10: Behavioral intention to use (BI) affects actual system use (AU) in using the KAN MIS application. This hypothesis is supported by Davis et al. (1989), Wang et al. (2005), and Shyu and Huang (2011).

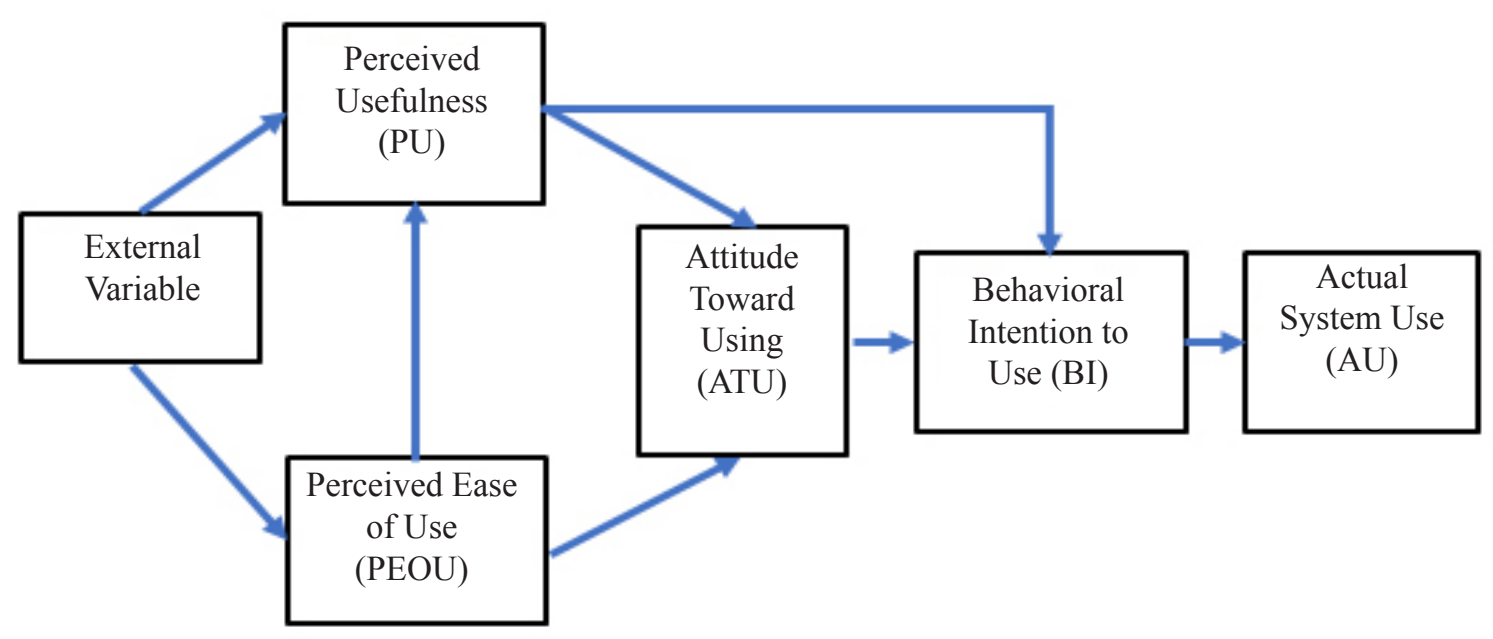

Figure 1. TAM theory flowchart (Davis et al. 1989)

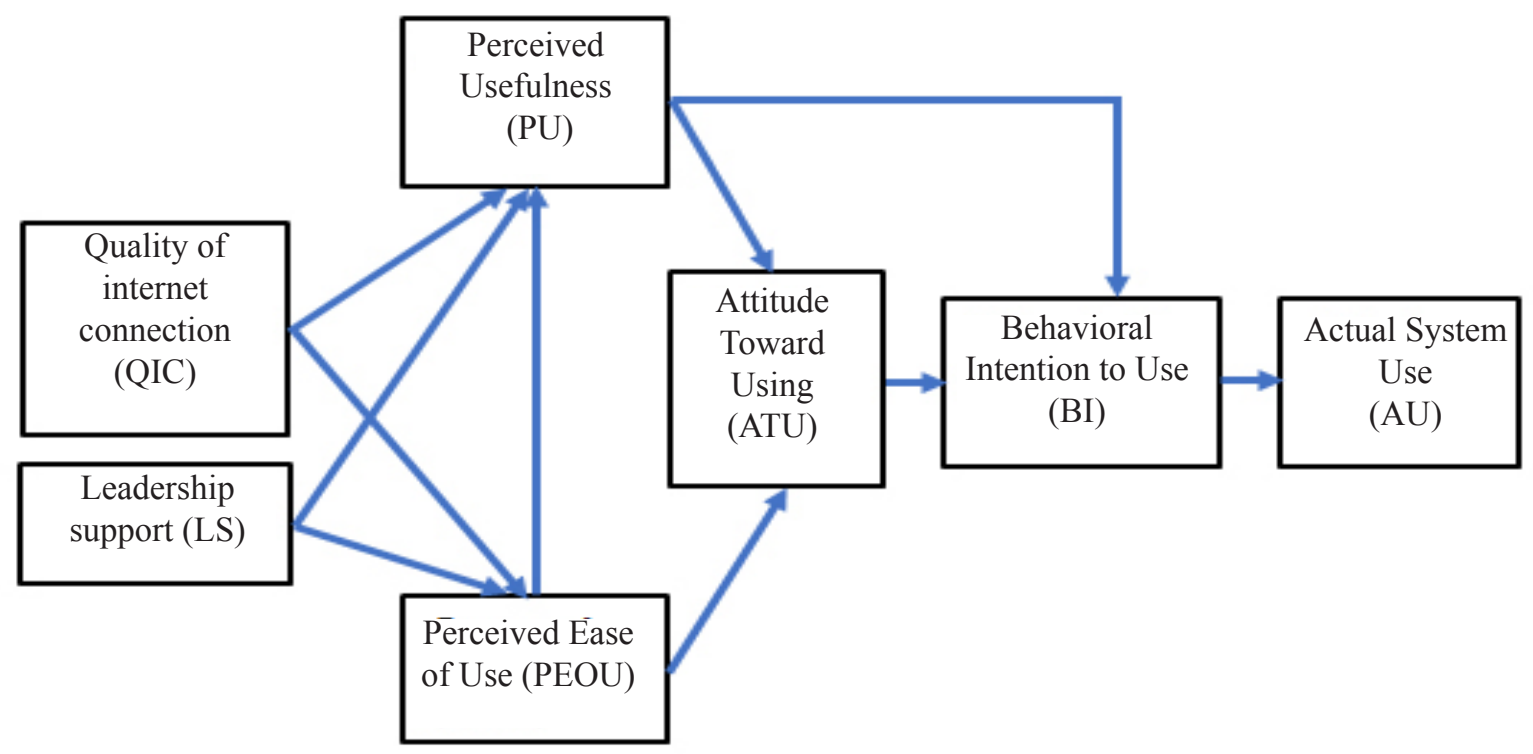

Figure 2. Flowchart of the TAM model of this research 


\section{RESULT}

The tendency of user behavior to continue to use (behavioral intention to use) the KAN MIS application was reflected from the conformity assessment bodies intending to use, choosing to use, and being committed to using the KAN MIS application. The actual system use was indicated by the categories of satisfaction of the conformity assessment bodies in use, increasing the intensity of use, each month will use, frequently use, and continue to use the KAN MIS application. The results of the evaluation of the outer model were as follows: If there were indicators that had a loading factor value of $<0.5$, a recalculation of the model must be carried out so that the loading factor of all reflective indicators was $>0.5$ as a criterion for the validity test of convergent latent constructs (Ghozali, 2014). Also, the model requirement had good validity if each latent variable with a reflective indicator had an average variance extracted of $>0.5$.

Figure 3 shows that all indicators had a loading factor value of $>0.5$, which means that all indicators had met the convergent validity requirements. Table 1 shows that the average variance extracted value of each latent variable had a value of $>0.5$, which means that the PLS model fulfilled good convergent validity requirements.
The next measurement, namely the reliability test, was used to prove the consistency and accuracy in measuring the construct. The reliability test was conducted by measuring composite reliability and Cronbach's alpha for latent variables. The ones with the value of $>0.7$ were reliable. Based on Table 1, all latent constructs had a good, accurate, and consistent reliability because they met the requirements with the composite reliability and Cronbach's alpha values of $>0.7$ for each latent construct.

The discriminant validity test was carried out on the principle that the gauges (manifest variables) of different constructs should not be highly correlated (Ghozali, 2014). Table 2 shows that the correlation value between constructs as a whole was less than the root value of the average variance extracted. It could be said that the model has met the conditions for discriminant validity. It means that the indicators in the latent construct were correct in measuring the latent variables.

The goodness of fit obtained in this research model was 0.799 . The value was more than zero, which means that this model was relevant as a prediction model. The bootstrapping results in Table 3 can answer the hypothesis in this study with the following explanation:

Table 1 Average variance extracted value, composite reliability and Cronbach's alpha

\begin{tabular}{lccc}
\hline & AVE & Composite Reliability & Cronbachs Alpha \\
\hline ATU & 0.868 & 0.952 & 0.924 \\
AU & 0.763 & 0.942 & 0.923 \\
BI & 0.898 & 0.963 & 0.943 \\
LS & 0.785 & 0.936 & 0.909 \\
PEOU & 0.705 & 0.934 & 0.915 \\
PU & 0.802 & 0.970 & 0.964 \\
QIC & 0.879 & 0.967 & 0.954 \\
\hline
\end{tabular}

Table 2. Correlation matrix and the root value of the average variance extracted between latent variables

\begin{tabular}{lccccccc}
\hline & ATU & AU & BI & LS & PEOU & PU & QIC \\
\hline ATU & $\sqrt{ }$ AVE $=0.932$ & & & & & & \\
AU & 0.865 & $\sqrt{ }$ AVE $=0.874$ & & & & & \\
BI & 0.900 & 0.843 & $\sqrt{ }$ AVE $=0.947$ & & & & \\
LS & 0.801 & 0.772 & 0.814 & $\sqrt{ }$ AVE $=0.886$ & & & \\
PEOU & 0.831 & 0.813 & 0.791 & 0.788 & $\sqrt{ }$ AVE $=0.840$ & & \\
PU & 0.915 & 0.837 & 0.892 & 0.826 & 0.886 & $\sqrt{ }$ AVE $=0.895$ & \\
QIC & 0.699 & 0.622 & 0.679 & 0.740 & 0.778 & 0.741 & $\sqrt{ }$ AVE $=0.938$ \\
\hline
\end{tabular}


Table 3. The value of the path coefficient and the t-statistic effect between latent variables

\begin{tabular}{lccc}
\hline & Path Coefficient & T-Statistic & R-square \\
\hline LS $\rightarrow$ PEOU & 0.468 & $14.257^{*}$ & 0.704 \\
QIC $\rightarrow$ PEOU & 0.432 & $13.124^{*}$ & \\
LS $\rightarrow$ PU & 0.329 & $9.425^{*}$ & 0.828 \\
QIC $\rightarrow$ PU & 0.024 & $0.696 \mathrm{tn}$ & \\
PEOU $\rightarrow$ PU & 0.608 & $17.617^{*}$ & 0.839 \\
PEOU $\rightarrow$ ATU & 0.096 & $2.118^{*}$ & \\
PU $\rightarrow$ ATU & 0.830 & $19.035^{*}$ & 0.838 \\
ATU $\rightarrow$ BI & 0.513 & $9.776^{*}$ & \\
PU $\rightarrow$ BI & 0.423 & $7.983^{*}$ & 0.711 \\
BI $\rightarrow$ AU & 0.843 & $56.413^{*}$ & \\
Note: $*$ t-statistic $>$ t-table (1.96) it means that the effect was significant at a significance level of 5\%; tn) the influence is not \\
significant
\end{tabular}

\section{Evaluation of the Structural Model (Inner Model)}

The structural model is used to describe the relationship from each variable to another and indicators to variables. The structural model is evaluated by looking at the significance of the relationship between the constructs. This can be seen from the path coefficient, which describes the strength of the relationship between the constructs. The sign in the path coefficient must be in accordance with the hypothesized theory, and the significance of the path coefficient can be seen from the $\mathrm{t}$-statistic value obtained from the bootstrapping process (resampling method). The PLS structural model in this study is portrayed in Figure 3.

\section{Effect of Quality of Internet Connection on Perceived Ease of Use and Perceived Usefulness}

Quality of internet connection had a significant influence on perceived ease of use with $\mathrm{t}$-statistical value $>\mathrm{t}$-table (1.96) at a significance level of 5\%. Quality of internet connection had an effect on perceived ease of use by 0.432 , which means the better the quality of internet connection (reflected by its four indicators), the better the perceived ease or perceived ease of use will be. In the study, the internet connection quality did not affect the perceived usefulness because of the t-statistic value $(0.69) \leq \mathrm{t}$-table (1.96) at the significance level of $5 \%$.

\section{The Effect of Leadership Support on Perceived Ease of Use and Perceived Usefulness}

Leadership support had a significant influence on perceived ease of use with a t-statistic value $>t$-table (1.96) at a significant level of 5\%. Leadership support had an effect on perceived ease of use by 0.468 , which means that the better Leadership support is reflected by the indicator of leadership instructions to use the system, the leader thinks that the system will save costs, motivation from the leadership, the leadership provides opportunities for training, the better the perceived ease of use will be. The structural model of perceived ease of use generated an R-square value of $70.4 \%$. It means that the diversity of perceived ease of use that the model could explain was $70.4 \%$, while other factors outside the model explained the remaining $29.6 \%$. Leadership support had a significant effect on perceived usefulness with statistical value $>$ t-table (1.96) at a significant level of $5 \%$. Leadership support had an effect on the perceived usefulness by 0.329 , which means that the leading indicator reflects the better leadership support for using the system, the leader considers that the system will provide costs, motivation from the leader, and the leadership provides opportunities for training, thus increasing the perceived benefits.

\section{Effect of Perceived Ease of Use on Perceived Usefulness and Attitude Toward using}

The perceived ease of use had a significant effect on the perceived usefulness with the $\mathrm{t}$-statistic value $>\mathrm{t}$-table (1.96) at a significant level of $5 \%$. The perceived ease of use affected the perceived usefulness by 0.608 , which means that the better the perception of ease of use (reflected by its six indicators), the better the perception of usability will be. The perceived structural usefulness resulted in an R-square value of $82.8 \%$, meaning that the perceived diversity of usefulness that the model was able to explain was $82.8 \%$. In comparison, the remaining $17.2 \%$ was the fact by other factors outside the model. 
The perceived ease of use had a significant effect on attitudes towards using because of the t-statistic value $>$ t-table (1.96) at the significance value of $5 \%$.

\section{Effect of Perceived Usefulness on Behavioral Intention to Use}

Perceived usefulness had a significant influence on behavioral intention to use with a t-statistic value $>$ $\mathrm{t}$-table (1.96) at the significance value of 5\%. Perceived usefulness affected behavioral intention to use by 0.423 , which means that the better the perceived usefulness (reflected by its eight indicators), the increased the behavioral intention to use will be. The structural model of behavioral intention to use generated an $\mathrm{R}$-square value of $83.8 \%$, meaning that the diversity of perceived usefulness that could be explained by the model is $83.8 \%$, while other factors outside the model explained the remaining $16.2 \%$.

\section{Effect of Perceived Usefulness on Attitude Toward Using}

Perceived usefulness had a significant effect on attitude toward using the t-statistic value $>$ t-table (1.96) at the significance level of $5 \%$. Perceived usefulness had an effect on attitude toward using by 0.830 , which means that the better the perceived usefulness (reflected by its eight indicators), the better the attitude toward using will be. The structural model of attitude toward using generated an R-square value of $83.9 \%$, which means that the diversity of attitude toward using that could be explained by the model was $83.9 \%$, while the remaining $16.1 \%$ was explained by other factors outside the model.

\section{Effect of Attitude Toward Using on Behavioral Intention to Use}

Attitude toward using had a significant effect on behavioral intention to use with a t-statistic value $>$ t-table (1.96) at the significance level of 5\%. Attitude toward using had an effect on behavioral intention to use by 0.513 , which means that the better the attitude toward using (reflected by its three indicators), the better the behavioral intention to use. The structural model of behavioral intention to use generated an R-square value of $83.8 \%$. The diversity of actual system use that the model could explain was $83.8 \%$, while other factors outside the model explain the remaining $16.2 \%$.

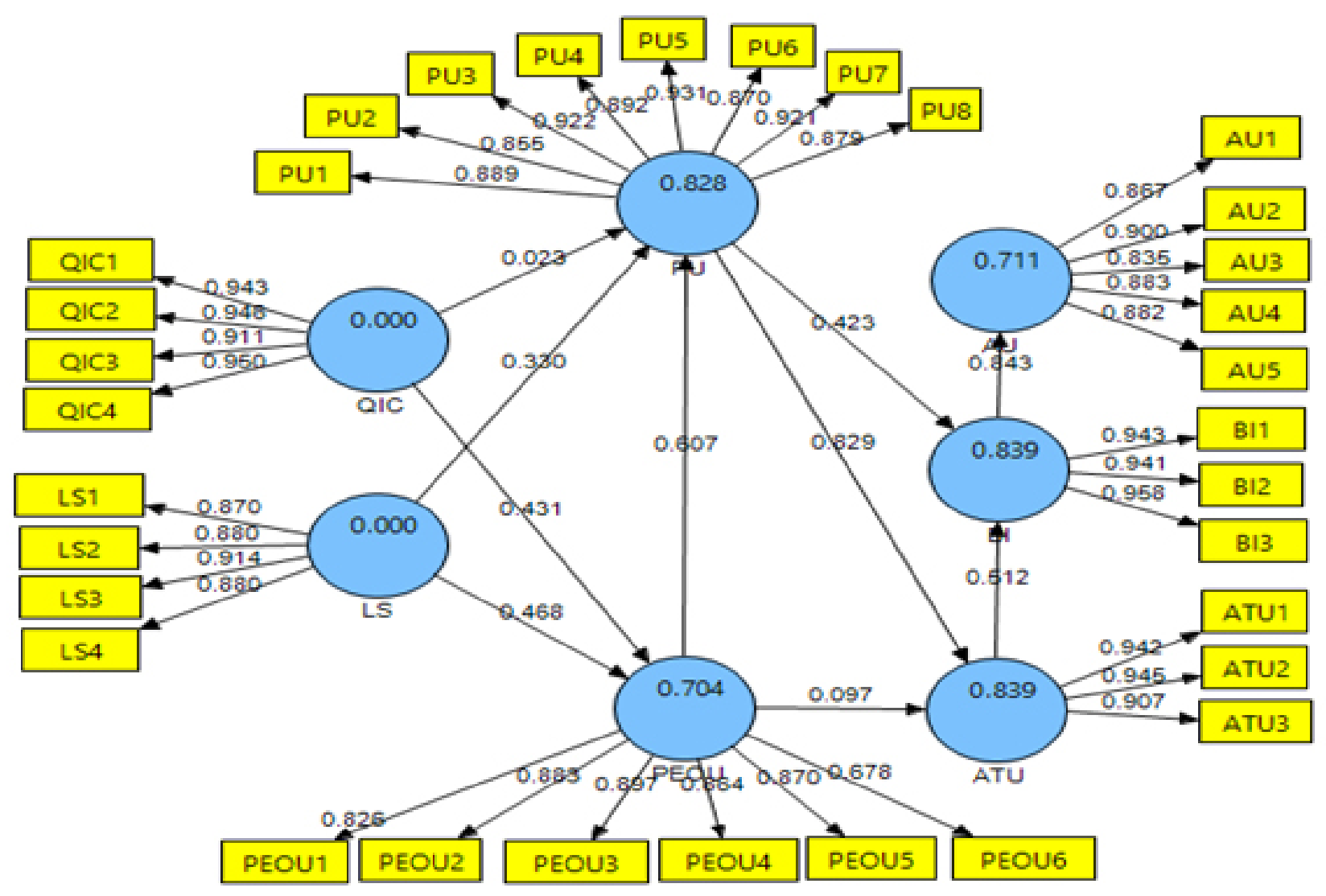

Figure 3. PLS structural model with loading factors 


\section{Effect of Behavioral Intention to Use on Actual System Use}

Behavioral intention to use had a significant effect on actual system use with the t-statistic value (1.149) > t-table (1.96) at the significance level of 5\%. Behavioral intention-to-use affected the actual system use by 0.843 , meaning that the better the behavioral intention (reflected by its three indicators), the better the actual system use will be. The structural model of actual system use generated an R-square value of $71.1 \%$, which means that the actual system use diversity that the model could explain was $71.1 \%$, while the remaining $28.9 \%$ was explained by other factors outside the model.

\section{Managerial Implication}

The results of this study provide several inputs that can be applied by management. The practical implication is to improve internet network capabilities by strengthening the server capacity of the KAN MIS application with internet network investment, increasing the motivation of the leadership towards the employees of the CABs with the socialization of the use of the KAN MIS application on a regular basis involving the leadership of the CABs in the framework of updating the application, increase the convenience in using the application. Top management is expected to receive input from this research so that the KAN MIS application can be more useful in the future.

\section{CONCLUSIONS AND RECOMMENDATIONS}

\section{Conclusions}

This study showed that the factors that significantly influenced the behavior of using the KAN MIS application were the quality of internet connection, leadership support, perceived ease of use, perceived usefulness, and attitudes toward using. By extending TAM, this study revealed results that support arguments made by other researchers claiming that quality of internet connection affected perceived ease of use, and leadership support (charismatic or transformational leadership style) affected perceived ease of use and perceived usefulness. This study also confirmed perceived ease of use and perceived usefulness as the determinants of attitude toward using that affected behavioral intention to use and actual system use.

\section{Recommendations}

This study has not measured the magnitude of the KAN MIS application's influence on work productivity in detail. Future studies could examine the impact of the KAN MIS application on work productivity by measuring the accreditation process time. Using the KAN MIS application will accelerate work productivity, especially accreditation services. The users of the KAN MIS application consist of CABs, assessors, and the secretariat of KAN. This study's limitation was that it only covered the CABs point of view as the KAN MIS application user. Further research should be about users of the KAN MIS application in terms of the accreditation process assessment team (assessors).

\section{REFERENCES}

Al-Somali SA, Gholami, R, Clegg, B. 2009. An investigationinto the acceptance of online banking in Saudi Arabia. Technovation 29 (2): 130-141. doi:10.1016/j.technovation.2008.07.004.

Chin S, Yoon S, Kim YS, Jung Y, Park SC, Chung M. 2004. A Project Progress Measurement and Management System. Proceedings of the 21st. South Korea:ISARC.

Davis FD. 1985. A Technology Acceptance Model For Empirically Testing New End-User Information Systems: theory and results. USA: Massachusetts Institute of Technology.

Davis FD. 1989. Perceived usefulness, perceived ease of use, and user acceptance of information technology. MIS. Quarterly 13(3): 319-340. doi: $10.2307 / 249008$.

Dumpit DZ, Fernandez CJ. 2017. Analysis of the use of social media in higher education institution (HEIs) using the technology acceptance model. International Journal of Educational Technology in Higher Education 14:5. doi: 10.1186/s41239017-0045-2.

Dwivedi YK, Rana NP, Janssen M, Lal B, Williams MD, Clement M. 2017. An empirical validation of a unified model of electronic government adoption (UMEGA). Government Information Quarterly 20:4C.

Fishbein M, Ajzen I. 1975. Belief, Attitude, Intention, and Behavior: An Introduction to Theory and Research. MA: Addison-Wesley.

Fonchamnyo DC. 2013. Customers' perception of e-banking adoption in cameroon: an empirical 
assessment of en extended TAM. International Journal of Economics and Finance 5(1): 166176. http://dx.doi.org/10.5539/ijef.v5n1p166.

Ghozali I. 2014. Structural Equation Modeling Metode Alternatif Dengan Partial Least Squares (PLS). Semarang: Badan Penerbit Universitas Diponegoro Semarang.

Hanseler J, Sarstedt M. 2013. Goodness of fit indices for partial least squares path modeling. Computer Statistics.http://dx.doi.org/10.1007/s00180-0120317-1.

Hubona GS, Kennick E. 1996. The Influence of External Variables on Information Technology Usage Behavior. Proceedings of the 29th Annual Hawaii Internasional Conference on System Sciences. USA: IEEE.

Lu J, Yu CS, Liu C, Yao JE. 2003. Technology acceptance model for wireless internet. Internet Research 13(3): 206-222. http://dx.doi.org/10.1108/ 10662240310478222.

Manalu LDU, Hermadi I, Ratono J. 2020. Studying the determinants of intention to use tokopedia for smes agribusiness products purchase. Indonesian Journal of Business and Entrepreneurship 6(1):111. http://dx.doi.org/10.17358/IJBE.6.1.1.

Nasri W, Charfeddine L. 2012. Factors affecting the adoption of internet banking in Tunisia: an integration theory of acceptance model and theory of planned behavior. The Journal of High Technology Management Research 23:1-14. http://dx.doi.org/10.1016/j.hitech.2012.03.001.

Neufeld D, Dong L. 2007. Charismatic leadership and user acceptance of information technology. European Journal of Information Systems 16: 494-510. http://dx.doi.org/10.1057/palgrave. ejis.3000682.

Pikkarainen T, Pikkarainen K, Karjaluoto H, Pahnila S. 2004. Consumer acceptance of online banking: an extension of the technology acceptance model. Internet Research 14(3): 224-235. http:// dx.doi.org/10.1108/10662240410542652.

Pradana M, Wijaksana TI. 2015. Managing Work Productivity Through Management of
Information System (Study on Telkom Indonesia Online Portal). American Scientific Publishers.

Saade R, Bahli B. 2005. The impact of cognitive absorption on perceived usefulness and perceived ease of use in online learning: an extension of the technology acceptance model. Information \& Management 42(2): $317-327$. http://dx.doi. org/10.1016/j.im.2003.12.013.

Schepers J, Wetzels M, Ruyter KD. 2005. Leadership styles in technology acceptance: do followers practice what leaders preach?. Managing Service Quality 15(6): 496-508. http://dx.doi. org/10.1108/09604520510633998.

Sholiha EUN, Salamah M. 2015. Structural equation modeling-partial least square untuk pemodelan derajat kesehatan kabupaten/kota di jawa timur (studi kasus data indeks pembangunan kesehatan masyarakat jawa timur 2013). Jurnal Sains dan Seni ITS 4(2).

Shyu SHP, Huang JH. 2011. Elucidating usage of e-government learning: a perspective of the extended technology acceptance model. Government Information Quarterly 28: 491-502. http://dx.doi.org/10.1016/j.giq.2011.04.002.

Venkatesh V, Morris MG, Davis GB, Davis FD. 2003. User acceptance of information technology: toward a unified view. MIS. Quarterly 27(3): 425-478.

Venkatesh V, Thong JYL, Xu X. 2012. Consumer acceptance and use of information technology: extending the unified theory of acceptance and use of technology. MIS. Quarterly 36(1):157178.

Venkatesh V, Thong JYL, Xu X. 2016. Unified theory of acceptance and use of technology: a synthesis and the road ahead. Journal of the Association for Information Systems 17(5): 328-376.

Wang CC, Hsu Y, Fang W. 2005. Acceptance of technology with network externalities: an empirical study of internet instant messaging services. Journal of Information Technology Theory and Application (JITTA) 6(4): 15-28. 